\title{
OOLOGY ON THE NORTHERN PLAINS: AN HISTORICAL PREVIEW
}

C. STUART HOUSTON, 863 University Drive, Saskatoon, Saskatchewan, S7N 0J8 and MARC J. BECHARD, Department of Biological Sciences, Marshall University, Huntington, West Virginia. 25701

As part of a study of native raptor populations on the North American prairie, we have surveyed oologic records for information on early bird distribution patterns. The senior author surveyed all issues of The Oologist from 1886 to 1894 and The Nidiologist (later spelled The Nidologist) from 1893 to 1896 and found interesting material on the nesting of prairie birds. Fewer useful items were located in The Young Oologist (1884-1885), Ornithologist and Oologist (1881-1893), The Hawkeye Ornithologist and Oologist (1888-1918), The Avifauna (1895-1897), The Ottawa Naturalist (1887-1918), and The Journal of Comparative Oology (1920-1922). The junior author studied raptor sets in Canadian and American museums, particularly the collection of the Western Foundation of Vertebrate Zoology (WFVZ) in Los Angeles. With over 120,000 catalogued sets, the WFVZ has by far the largest collection of North American raptor eggs and includes nearly 200 falconiform sets collected in the prairie provinces aloné." In this and subsequent articles, we will summarize the record and attempt to give some insight into the once popular hobby of egg collecting and the motives behind the ambitious collecting trips that were made to the northern plains.

The first oologist to visit the Northern Plains was Lieutenant (later Captain) Thomas Wright Blakiston, magnetic observer with the Palliser expedition. He was stationed at Fort Carlton, $80 \mathrm{~km}$ north of present-day Saskatoon, from 23 October 1857 through early June 1858. An enthusiastic ornithologist, Blakiston's observations were published in The Zoologist and The Ibis between 1859 and $1863 .{ }^{\circ}$ An active collector of bird specimens, Blakiston also sent a few eggs taken in 1858 to the Smithsonian Institution in Washington, D.C. These were: 2 sets (6 eggs each) of Brewer's Blackbird on 3 June, 1 set of Goshawk (4 eggs) on 7 May, 1 set of Merlin (4 eggs) on 25 May, and 1 set each of American Coot, Sharp-tailed Grouse, and Mallard without specific dates. Only $1 \mathrm{egg}$ of each of these sets is extant. Bendire, in Volume 1 of his Life Histories of North American Birds published by the Smithsonian in 1892 ,

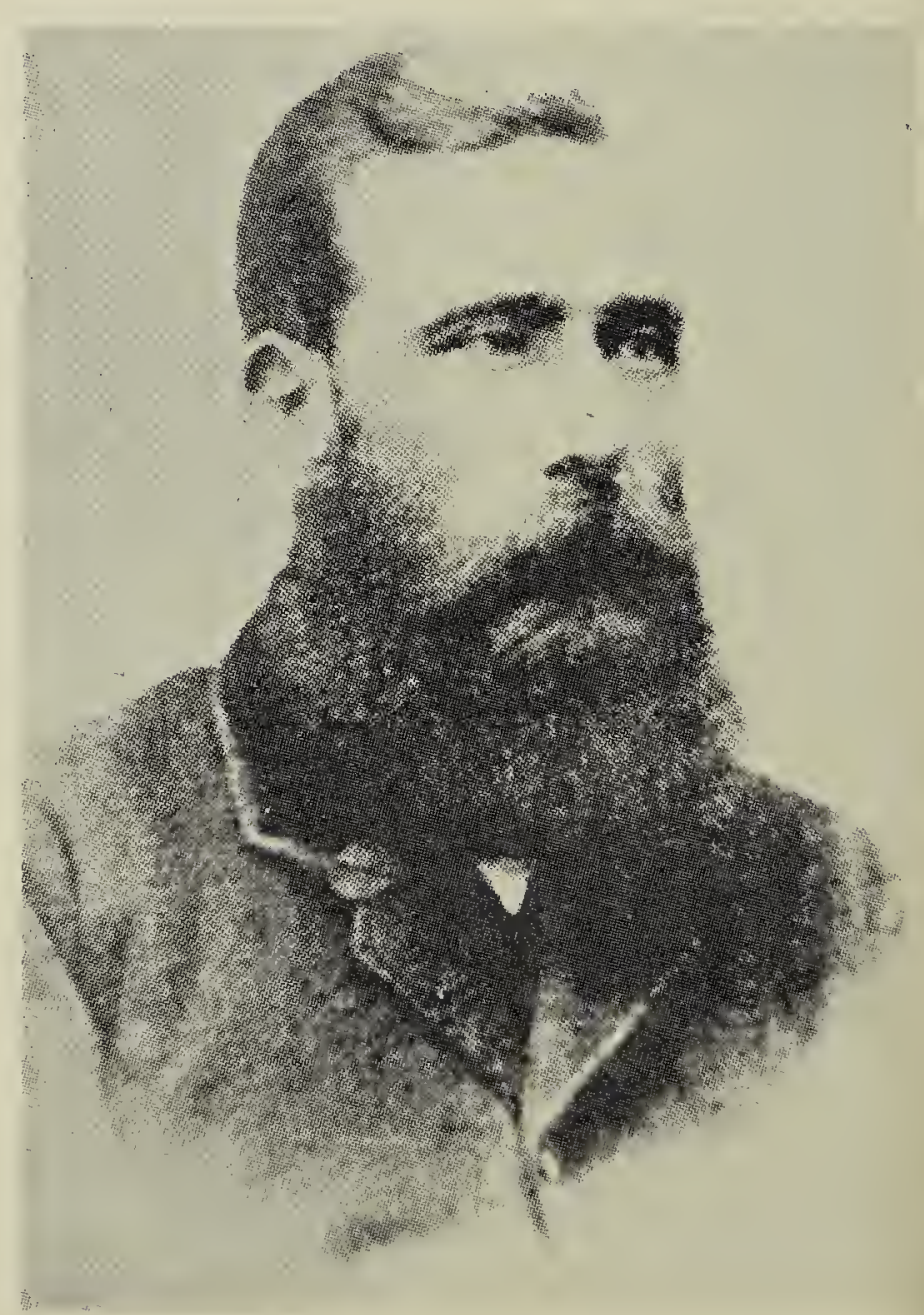

Thomas Blakiston.

Courtesy Saskatchewan Archives Board 
correctly credited Blakiston with being the first man ever to collect eggs of the Ferruginous Hawk. On a buffalo hunting trip to the Anerley Lakes about $170 \mathrm{~km}$ SSW of Carlton, Blakiston had found two Ferruginous nests, one with five eggs and one with four eggs on 29 and 30 May. $^{8}$ One of these eggs is shown in colour in Bendire's plate $9 .^{2}$

Egg collecting did not begin in earnest on the northern plains until about 1890. Prior to that, fur traders and early settlers were more interested in eggs as a source of food. Samuel Hearne (1795), who founded the first inland trading post of the Hudson's Bay Company at Cumberland House in 1774, for instance, remarked that the eggs of the Trumpeter Swan were "so big that one of thern [was] sufficient meal for a moderate man without bread or any other addition." Because they were so easy to collect, eggs of ducks, geese, Sharp-tailed Grouse, and the ubiquitous Upland Sandpiper were used for food by settlers in the Wallace district northeast of Yorkton in 1892 (Kred Langstaff, pers. comm.). In North Dakota, eggs of colonial species such as Common Tern and Franklin's Gull were served in hotels as late as $1886 .{ }^{14}$

Within the first decade of settlement, the introduction of domestic poultry decreased the pressure on wild bird eggs for food and by the end of the century, eggs were far more highly valued by oologists for their shells. By then, oology had become popular throughout North America. As the demand for eggs of western species increased, nests were more frequently raided by egg collectors than by foraging settlers.

One hundred years ago, the energy that might today be devoted to listing, observing, photographing, or banding was then more often devoted to finding nests and collecting their eggs. Many well known ornithologists actually began with an interest in oology. A.C. Bent, for example, had "one of the largest private collections." In Saskatchewan, the best example of oologist-turned-ornithologist was the late Maurice $G$. Street who obtained breeding records for no less than 141 species within $30 \mathrm{~km}$ of Nipawin.

Oology was then not only an acceptable hobby, but was more popular than philately or numismatics, part of the human passion to collect things of unusual beauty. The more serious collectors prided themselves with keeping accurate records. Data slips for each set listed observations such as the location of the nest, date of collection, species of nest tree, height of the nest, clutch size, and progress of incubation, as well as occasional interesting bits of information about difficulties encountered and chances taken while collecting. Many were intrepid climbers and apparently valued the eggs more than "life or limb."

Published accounts of such adventures made popular reading and many journals dealing with oology appeared. Some were short-lived, but The Oologist in its first years had a circulation of 2500, a much larger readership than The Auk which then had a circulation of only $500 .{ }^{13}$

Oologists often bragged of the size of their collections. Dr. Morris Gibbs told, for example, how K.R. Wilhelm collected 113 Buteo eggs on a three day float down the St. Joseph River in southern Michigan. ${ }^{6}$ J. Parker Norris, Jr., a Philadelphia lawyer, proudly boasted of owning 22,000 sets of nearly 600 species. ${ }^{17}$ Norris had 970 eggs of the Kentucky Warbler, "the result of twelve years of hard work." As for his 150 Red-tailed Hawk eggs, Norris argued that "one could not begin to show all the variation that the eggs of that species are subject to in a series of that number." 12 In 1914, E.J. Darlington wrote a note in memory of his late friend William B. Crispin, describing how Crispin had personally collected 966 


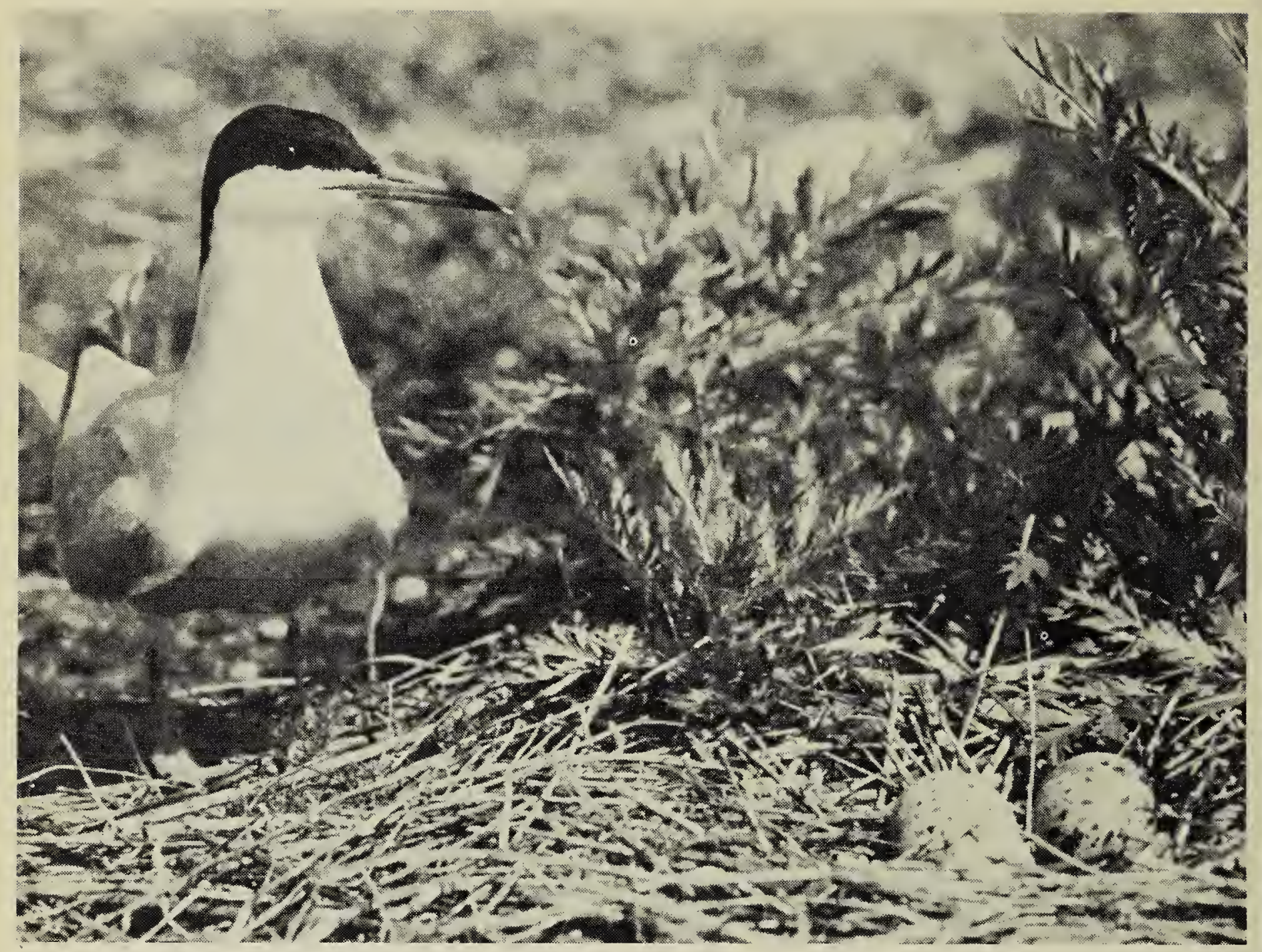

Common Tern at nest.

Wayne Lynch

Osprey eggs. Darlington defended this seeming greed by adding: "they lay a second set when their nest is molested, so what's the objection to us taking their eggs, that are so beautiful in various shapes and colours."

Journals also provided dealers with an advertising medium. E.S. Rolfe, in 1899, for example, advertised in The Oologist that he had Bittern and Avocet eggs for sale at $40^{\star}$, Willet and Baird's Sparrow at $30^{\circ}$, and Western Horned OWl at $60^{\circ}$ each. W.E. Saunders, one of Canada's leading ornithologists, ran an ad in The Oologist offering a California Condor egg for sale at $\$ 150 .^{16}$

Troubled by the reports of indiscriminate, wholesale collecting, E.S. Rolfe of Minnewaukon, North Dakota was one of the first oologists to publish warnings of the possible harmful effects of egg collecting. ${ }^{14}$ Rolfe mentioned how in 1883 "the White Pelican bred on Devil's Lake in North Dakota in great numnbers and that a thrifty idler [had] shipped one or two barrels of their eggs to an Eastern dealer . . . since that time, they have not been known to nest there." Such reports were largely ignored and the hobby remained popular until the 1930s. During that time avid collectors throughout the northern plains included: Archibald Henderson, J.E. Houseman, G.F. Dippie, George Cook, Tom Randall, Evan Thomson, N.V. Fearnehough and Frank Farley in Alberta; Chris Forge, Ernest Norman, David Ogg, and John Cruttenden in Manitoba; Eugene Rolfe, Alfred Eastgate, E. Dodd, J.D. Currie, George Davy, G. Withey, G. Abbey and Frederick Philipp in northern North Dakota; and Edward Arnold, Walter 
Raine, Frank Baines, W.C. Goelitz, S.J. Darcus, and W.A. and J.E. Bowman in Saskatchewan. Because of mounting criticism and a change of emphasis and interests, oology lost popularity during the 1940s and 1950s. The collection, sale, and trade of wild bird eggs became illegal. Since the mid 1960s nonscientific egg collecting has ceased.

Today, there are few private collections left. Nelson Hoy's collection of over 15,000 sets at Medina, Pennsylvania was the last large, private collection maintained in North America. The surviving egg sets, including Hoy's, are now maintained by museums throughout the United States and Canada. The data therein offer insight into the distribution of raptors at the turn of the century. Subsequent articles will deal with Edward Arnold, one of the foremost collectors and then regionally with those oologists who were active in the prairie regions of Manitoba, Saskatchewan, Alberta, Montana and North Dakota.

'BARNES, R.M. 1914. What an editor saw. And those he met. Oologist 31:10-17.

${ }^{2}$ BENDIRE, C. 1892. Life Histories of North American Birds with special reference to their breeding habits and eggs. Smithsonian Contributions to Knowledge, vol. 28 Washington: Govt. Printing Office.

${ }^{3}$ BLAKISTON, T. 1859. Scraps from the far west. Zoologist 17:6318-6325 and 6373-6376.

${ }^{4}$ BLAKISTON, T. 1861-1863. On birds collected and observed in the interior of British North America. Ibis 3:314-320. Ibis 4:3-10. Ibis 5:39-87 and 121-155.

${ }^{5}$ DARLINGTON, E.J. 1914. Ospreys. Oologist 31:199-200.

"GIBBS, M. ("SCOLOPAX"). 1891. A perfect collection. Oologist 8:35-36.

'HEARNE, S. 1795. A Journey from Prince of Wales's Fort in Hudson's Bay to the
Northern Ocean. London: A. Strahan and T. Cadell. xliv + 458 pp.

'HOUSTON, C.S. 1976. A bird-watcher's outing in 1858. Sask. History 29:14-25.

HOUSTON, C.S. and A. SCHMIDT. 1981. History of Richardson's Merlin in Saskatchewan. Blue Jay 39:30-37.

${ }^{10}$ HOUSTON, C.S. and M.G. STREET. 1959. The Birds of the Saskatchewan River, Carlton to Cumberland. Regina: Sask. Nat. Hist. Soc., Spec. Publ. No. 2, 205 pp.

${ }^{11} \mathrm{KIFF}$, L.F. 1979. Bird egg collections in North America. Auk 96:746-755.

${ }^{12}$ NORRIS, J.P., JR. 1899. The utility of large series of eggs and nests: a reply to Dr. F.H. Knowlton. Osprey 4:28-29.

${ }^{13}$ PALMER, T.S. 1933. A brief history of the American Ornithologists Union. pp. 727 in: Fifty Years' Progress of American Ornithology, 1883-1933. Lancaster.

${ }^{14}$ ROLFE, E.S. 1896 . The passing of species. Oologist 13:42-44.

${ }^{15}$ ROLFE, E.S. 1899. Choice North Dakota sets. (advt.) Oologist 16:36.

${ }^{16}$ SAUNDERS, W.E. 1904. California Condor's egg (advt.) Oologist 21:204.

${ }^{17}$ TAYLOR, H.R. 1895. Some big egg collections. Nidiologist 2:154-156.

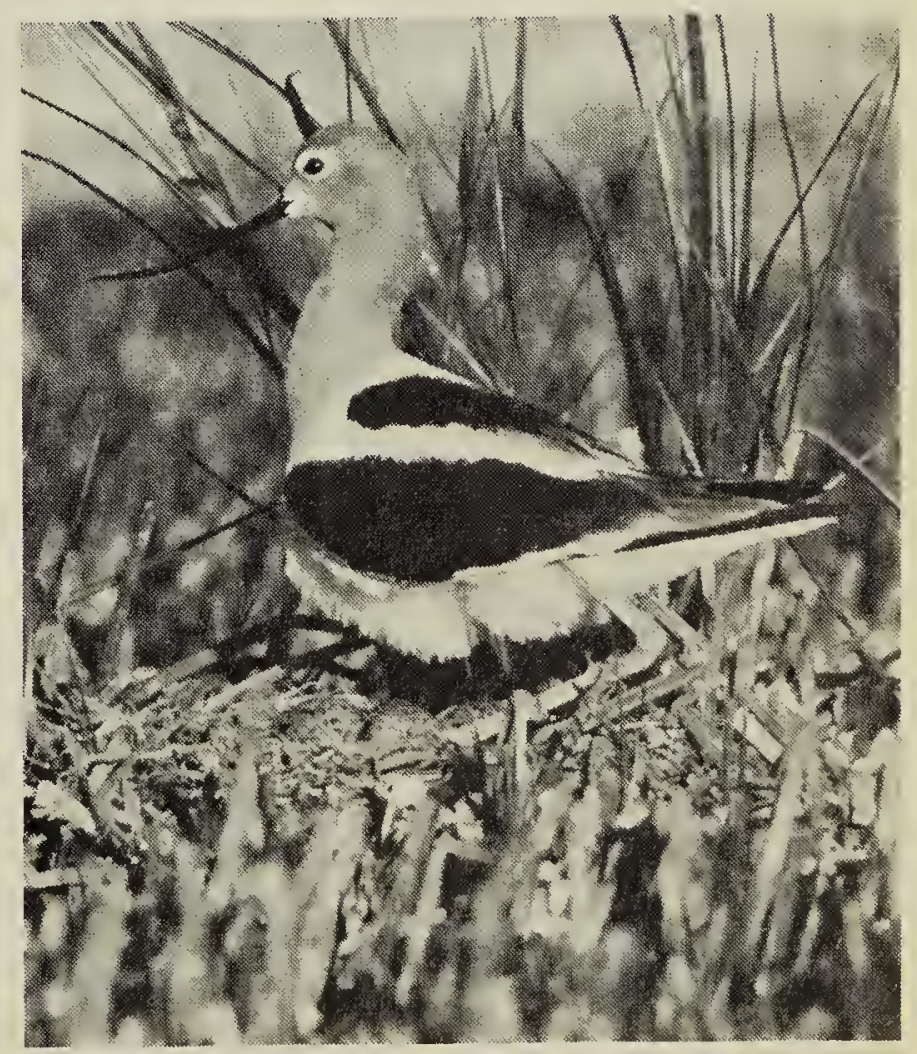

American Avocet on eggs.

G. W. Beyersbergen 